\title{
Historiallisen toimijuuden rakentuminen $\$$ lukiolaisten esseevastauksissa
}

\author{
Hilkka Paldanius
}

\section{Johdanto}

Tässä artikkelissa tarkastelen lukion historian oppiaineessa kirjoitettavia esseevastauksia kielenkäyttönä, johon opiskelijat ovat sosiaalistuneet osana historian opiskelua ja kouluopetusta. ${ }^{1}$ Kieliyhteisön ja tekstien suhde on keskiössä tiedonalakohtaisten tekstitaitojen (disciplinary literacies) käsitteessä, jossa korostuu se, miten eri tiedonalojen tavat hahmottaa ja kuvata maailmaa vaikuttavat tiedonalojen kieleen sekä tekstitaitoihin (Moje, Stockdill, Kim \& Kim 2011). Ajatus tekstitaidoista tiedonalakohtaisina taitoina näkyy myös vuonna 2016 käyttöön otetussa lukion opetussuunnitelmassa, jossa puhutaan monilukutaidosta (LOPS 2015: 35). Kyseessä on uusi, kaikille yhteinen aihekokonaisuus. Monilukutaito laajentaa vuoden 2003 opetussuunnitelmaan sisältynyttä tekstitaitojen käsitettä: kunkin oppiaineen opiskelu ajatellaan myös oppiaineen tekstitaitojen opiskeluna, joka kulkee käsi kädessä sisältöjen hallinnan kanssa. (Luukka 2013; Harmanen 2016.) Tekstitaitoja ei siis nähdä ainoastaan yksilön kognitiivisina taitoina vaan taitoina, joihin sosiaalistutaan yhteisössä toimimalla ja joita voidaan opettaa eri oppiaineissa (Fang \& Coatoam 2013: 628; Luukka 2009, 2013; Leinhardt \& Young 1998). ${ }^{2}$ Eri tiedonalojen tekstitaitojen tutkimus on opetussuunnitelmauudistuksen myötä tarpeellista, jotta tiedonalojen käytänteitä tunnistettaisiin ja tekstitaitojen opetusta voitaisiin kehittää.

Tekstitaitojen tiedonalakohtaisuus näkyy eri oppiaineiden tavoitteissa: historian oppiaineessa painottuu se, että historian oppimiseksi ja ymmärtämiseksi ei riitä irrallinen sisältötiedon ulkoluku, vaan opetuksen keskeisenä lähtökohtana ovat historian tiedonmuodostuksen piirteet ja historiallisen ajattelun opettaminen (LOPS 2015: 186; Veijola 2016: 14). Historiallinen tieto rakentuu keskeisesti syyn ja seurauksen sekä muutoksen ja jatkuvuuden tarkastelemiselle sekä näiden uskottavalle selittämiselle. Tietoa keskeisesti kuvaava piirre on myös sen tulkinnallisuus, sillä historiatieto perustuu eri aikakausina tuotettuihin lähteisiin ja lähteistä tehtäviin tulkintoihin. (Rantala \& Aho-

1. Artikkeli on osa väitöskirjatyötä, jota on rahoittanut Koneen Säätiö. Väitös liittyy Suomen Akatemian rahoittamaan hankkeeseen Engaging in disciplinary thinking: historical literacy practices in Finnish general upper secondary schools. Rahoittajan lisäksi kiitän nimettömiä arvioijia saamistani arvokkaista kommenteista.

2. Kognitiivisen ja sosiaalisen lähestymistavan eroista ks. esim. Luukka 2009: 14-16. 
nen 2015: 152.) Syy ja seuraus, muutos ja jatkuvuus sekä tiedon tulkinnallisuus ovat myös opetussuunnitelmassa keskeisiä historiatietoa kuvaavia käsitteitä (LOPS 2015: 170).

Historian selittämisen tavat ovat kytköksissä kielellisiin piirteisiin, joilla teksteissä esitetään tapahtumiin vaikuttaneita toimijoita. Historiassa syy-seuraussuhteita esitetään usein abstraktien toimijoiden välityksellä, jolloin tapahtumien taustalla olevat inhimilliset toimijat jäävät taka-alalle (Schleppegrell \& de Oliveira 2006: 256) ja valtioita personoidaan esittämällä ne inhimilliseen toimintaan viittaavissa prosesseissa (Halldén 1998). Koulun teksteistä vastaavia piirteitä on havainnut myös maantiedon ja biologian oppikirjoja tutkinut Pirjo Karvonen (1995), jonka mukaan oppikirjoissa on tavanomaista korostaa asioiden välisiä yhteyksiä tapahtumien aiheuttajien sijaan (mts. 175). Historian tekstitaidoista opiskelijoille haastavana onkin näyttäytynyt juuri syy-seuraussuhteiden ilmaiseminen (Martin 2002; Coffin 2006; de Oliveira 2011). Lisäksi tutkimusten mukaan historian opiskelussa ongelmia tuottavat muun muassa argumentointi (Rantala 2012: 202) ja ristiriitaisten lähteiden tulkitseminen (Veijola \& Mikkonen 2016); opiskelijoilla on usein taipumusta selittää menneisyyden tapahtumia perustelemalla niitä ihmisten toiminnan ja yksittäisten tapahtumien kautta, kun taas historioitsijat nojautuvat enemmän rakenteellisiin kokonaisuuksiin (Coffin 2006: 47; Halldén 1998: 135). Historian oppiaineessa opittavia tekstitaitoja ja siinä tuotettavia tekstejä ei kuitenkaan ole tutkittu Suomessa lingvistisestä näkökulmasta.

Tässä artikkelissa tarkastelen historiatiedon rakentumista lukiolaisten esseevastauksissa, joiden aiheena on kylmän sodan aloittajan pohtiminen annettujen historiallisten dokumenttien pohjalta. Analysoin teksteistä, miten kirjoittajat tulkitsevat ja kielentävät käsityksiään kylmän sodan aloittajasta: millaisena toimintana historialliset tapahtumat esitetään, kuka tai mikä esseissä esitetään tapahtumia aikaansaavana toimijana ja mikä on toiminnan mahdollinen kohde? Lähestyn historiallista toimijuutta lausetasolla tehtävänä kielellisenä valintana, joka vaikuttaa menneisyyden tapahtumien representoitumiseen esseissä. Valinnoilla en kuitenkaan tarkoita opiskelijoiden tietoisesti kirjoittaessaan tekemiä valintoja (ks. Thibault 1987: 604) vaan tekstintutkimuksellisten lähtökohtieni pohjalta sitä, miten kieliyhteisön tekstikäytänteet ja kielenkäyttötavat näkyvät historiatiedon rakentumisessa. Viitekehykseni on systeemisfunktionaalisessa kieliteoriassa, jonka mukaan kaikki tekstit ilmentävät yhtäaikaisesti kielen eri metafunktioiden merkityksiä (Halliday 1973: 66). Tutkimuskysymykseni kuitenkin ohjaa keskittymään teksteihin muodostuviin ideationaalisiin eli maailmaa kuvaaviin merkityksiin, ja kaikkien metafunktioiden samanaikainen tarkasteleminen voisikin olla metodologisesti haasteellista (ks. Shore 2012b: 159).

Tutkimukseni kohdistuu historian oppiaineessa tuotettuihin dokumenttipohjaisiin esseevastauksiin, mikä on opetussuunnitelmauudistuksen ja monilukutaidon käsitteen myötä ajankohtainen näkökulma historian tekstitaitoihin. Esseevastaukset edustavat yleistä opiskelussa ja arvioinnin perusteena käytettävää tekstiä, jonka kaltaisia kirjoitetaan historian kurssikokeissa ja myös ylioppilaskirjoituksissa. Esseevastaukset ovat siten osa tekstiverkostoa. Tähän verkostoon kuuluvat opiskelijoiden aiemmin kirjoittamat historian ja muiden oppiaineiden esseevastaukset, joiden pohjalta heille muodostuu 
malleja koulussa kirjoitettavista teksteistä. ${ }^{3}$ Tähän verkostoon kuuluvat myös tehtävänannot, oppikirjat, suullinen opetus, opetussuunnitelmat sekä muut koulumaailman ja yhteiskunnan säätelevät tekstit (ks. Makkonen-Craig 2008: 213). Tiedonalakohtaisten tekstitaitojen kehyksessä esseevastauksiin vaikuttavat myös historian tiedonalalla vallitsevat tavat kielentää todellisuutta.

Tiedonaloille ominaisten tiedon esittämistapojen hallinta ei ole vain tekstien tuottamisen vaan myös tiedonalan diskurssin ymmärtämisen ja siihen sosiaalistumisen kysymys. Tutkimuksessani käsite diskurssi tarkoittaa yhteisön vakiintuneita kielentämisja puhetapoja (ks. Pietikäinen \& Mäntynen 2009: 27). Puhun siis esimerkiksi oppikirjadiskurssista, historian diskurssista, politiikan diskurssista ja tieteellisestä diskurssista, jotka viittaavat esseevastauksia ympäröiviin puhetapoihin. Tutkimusotteeni on deskriptiivinen, joten tavoitteeni ei ole arvottaa sitä, miten esseevastauksissa tulisi kielentää historiatietoa. Koska tekstit ovat opiskelijoiden tekstejä, huomioin myös sen, että kirjoittajien taidot ovat erilaisia eivätkä kaikki esseet välttämättä vastaa tehtävänantoon halutulla tavalla (ks. esim. Juvonen 2014: 16). Analysoimani esseet eivät siten välttämättä vastaa opettajien odotuksia. Se, mitä koulussa kirjoittamisesta, historian diskurssista ja muista esseiden tilannekontekstiin kuuluvien tekstien piirteistä on aiemmissa tutkimuksissa sanottu, tarjoaa kuitenkin lähtökohtia esseiden tarkastelulle.

Koulussa kirjoitettavia esseevastauksia on aiemmissa tutkimuksissa luonnehdittu muun muassa ekspositorisiksi esseiksi (Schleppegrell 2004: 88; de Oliveira 2011), argumentoiviksi esseiksi (Hyland 1990; Lampinen 2005) sekä ongelmapohjaisiksi esseiksi (problem-based essay; Greene 1994). Opiskelijat sosiaalistuvat koulussa kirjoittamisen käytänteisiin myös muilla kuin historian oppitunneilla. Äidinkielen esseestä on käytetty nimitystä pohtiva essee (Juvonen 2011: 231), jonka vaatimus vaihtoehtoisten näkökulmien esittelystä ja näkökulmien sijoittamisesta kirjoittajan omaan pohdintaan sopii myös historian esseiden vaatimuksiin (vrt. Historian kokeen hyvän vastauksen piirteet 2015). Äidinkielen tekstitaidon ylioppilaskokeessa kirjoitettavat vastaustekstit taas edellyttävät aineistona olevien tekstien analysointia, erittelemistä, tulkintaa ja hyödyntämistä osana vastaustekstin kirjoittamista (Leino 2006; Valtonen 2011; Äidinkielen kokeen määräykset 2017). Nämä vaatimukset ovat osittain yhteneväisiä aineistopohjaisen historian esseevastauksen kanssa.

Äidinkielen ja kirjallisuuden oppiaineessa kirjoitettavia aineistopohjaisia tekstejä ovat tutkineet esimerkiksi Maarit Berg (2011) referoinnin ja Päivi Valtonen (2012) uutisen tekstilajin tuottamisen näkökulmasta. Valtonen (2011: 352) huomauttaa, että reaalikokeen vastaus eroaa äidinkielen tekstitaidon kokeesta siten, että tekstitaidon kokeessa ei vaadita yhtä laajamittaista sisällön hallintaa ja siinä kiinnitetään enemmän huomiota tekstin kieliasuun. Tätä väitettä tukee ainakin Jukka Rantalan ja Anna Veijolan (2016) historian tekstitaitoja pedagogisesta näkökulmasta tarkasteleva tutkimus, jossa opiskelijoilla oli tämän tutkimuksen kanssa yhteneväinen tehtävänanto. Heidän mukaansa (mt.) tehtävänannon aineiston hyödyntämisessä ongelmallista oli se, jos kirjoittaja ei sitonut dokumenteista tekemiään huomioita niin sanottuun historian kontekstitietoon eli opiskelijalla olevaan historian sisältötietoon.

3. Tekstilajien prototyyppisyydestä ks. esim. Mäntynen 2006: 63-64. 
Artikkelissa tarkastelen tehtävänantoon liittyvien dokumenttien heijastumista esseevastauksiin rakentuvissa toimijuuksissa ja ideationaalisissa merkityksissä, eli en keskity referoinnin keinoihin ja lähteiden hyödyntämiseen tekstilajin funktioiden toteutumisen kannalta. Tarkastelemalla historiallisen toimijuuden rakentumista esseevastauksissa kuvaan sitä, miten esseevastauksen kontekstuaaliset piirteet, kuten lukio-opiskelu, historian tiedonala sekä esseevastauksen tehtävänanto, heijastuvat näissä teksteissä ja mitä huomiot kertovat historian tiedonalakohtaisista tekstitaidoista.

Artikkeli rakentuu seuraavasti: Toisessa luvussa esittelen systeemis-funktionaalista kieliteoriaa tutkimuksen teoreettisena ja metodologisena viitekehyksenä sekä toimijuutta transitiivisuussysteemin ilmiönä. Kolmannessa luvussa esittelen aineiston, esseiden tehtävänannon ja siihen liittyvät oheisdokumentit. Neljännessä luvussa analysoin historiatiedon rakentumista ihmisille ja ihmiskollektiiveille annetun toimijuuden näkökulmasta ja viidennessä luvussa sitä, miten toimijuus rakennetaan historiallisia olosuhteita ja tapahtumien välisiä syy-seuraussuhteita korostavissa prosesseissa. Kuudennessa luvussa pohdin tekemiäni huomioita historiallisen toimijuuden ilmaisemisen tavoista ja havaintojeni suhteutumista esseiden tilannekontekstin muuttujiin sekä historian tekstitaitoihin.

\section{Systeemis-funktionaalinen kieliteoria toimijuuden tarkastelussa}

Tässä tutkimuksessa tarkastelen kieltä ja tekstejä systeemis-funktionaalisen kieliteorian (SF-teoria) näkökulmasta. SF-teoriassa kieli ajatellaan yhtenä sosiaalisen toiminnan muotona, jolloin kieltä, tekstejä ja niiden kontekstia ei nähdä toisistaan irrallisena. (Halliday 1973, 1978.) Teoria soveltuu siten hyvin sosiokulttuuriseen tekstitaitokäsitykseen nojaavan tutkimuksen pohjaksi. SF-teoriassa teksti on sellaisten kielellisten valintojen ilmenemismuoto, jonka tietty tilannekonteksti (context of situation) mahdollistaa (Halliday 1978: 122; Luukka 2002: 89). Tilannekontekstilla tarkoitetaan tekstin konkreettista ja aikapaikkaista esiintymisyhteyttä, jossa on yhtä aikaa kolme tasoa: ala (field), osallistujaroolit (tenor) ja ilmenemismuoto (mode). Nämä tasot reaalistuvat tekstin sanastolliskieliopillisissa valinnoissa. Sanastollis-kieliopillisissa piirteissä tilannekontekstin tasoja vastaa kolme metafunktiota, jotka ovat ideationaalinen, interpersoonainen ja tekstuaalinen. (Halliday 1978: 123; Shore 2012a: 135, 146.)

SF-teoriassa tekstien tarkastelu sidotaan siis aina sosiaaliseen tilanteeseen, jossa ne syntyvät ja jossa niitä käytetään, sillä tilannekontekstin ja tekstin suhde on jatkuvassa vuorovaikutuksessa (Halliday 1978: 139); tietyt kielelliset valinnat ovat toisia todennäköisempiä tietyssä tilanteessa (ks. Luukka 2002). Tästä johtuen suhteutan analyysissa tekemiäni havaintoja tekstien esiintymisyhteyteen: esseissä tehdyt kielelliset valinnat kietoutuvat historian tiedonalan ja oppiaineen diskursseihin, esseen tekstilajiin ja tehtävänantoon sekä tehtävänantoon liittyviin historiallisiin dokumentteihin.

Tilannekontekstin osat ja niitä heijastavat tekstin metafunktiot ilmenevät kielessä yhtäaikaisesti, eli samat sanastollis-kieliopilliset piirteet voivat rakentaa merkityksiä eri metafunktioista. Ideationaalinen metafunktio ilmentää kielen transitiivisuussysteemissä tehtyjä valintoja eli maailmaa kuvaavia valintoja. Interpersoonainen metafunktio kattaa 
kielen piirteet, jotka ilmentävät puhujan asenteita ja arvoja tai hänen rakentamaansa suhdetta itsensä ja kuulijan välille. Tekstuaalinen metafunktio taas tarkoittaa tekstin rakentumista ja jäsentymistä ilmentäviä kielen tasoja, kuten temaattista kehittelyä, koheesiota ja lauseiden yhdistymistä. (Halliday 1973: 106; 2014: 213; Luukka 2002: 99.)

Tarkastelen historian tapahtumien esittämistä esseissä ideationaalisesta näkökulmasta, eli analyysin kohteena on se, kuka tai mikä menneisyyden tapahtumien kuvaamisessa esitetään toimijaksi, mikä on toiminnan mahdollisena kohteena ja millaisin toiminnan ja olemisen tavoin tapahtumia kuvataan. Tarkastelen siis kielen transitiivisuussysteemissä tehtyjä valintoja eli prosessi- ja osallistujatyyppejä. Ideationaalisten merkitysten tarkastelussa hyödynnän SF-teorian mukaista kuvausta prosessityypeistä (Halliday 2014) sekä Susanna Shoren (1992, 2012a, 2012b) suomen kieleen soveltamaa prosessityyppien analyysia.

SF-teoriassa prosessi (process) tarkoittaa laajasti koko lausetta tai kapeammin lauseen ytimessä olevaa verbiä. Laajasti ymmärrettynä prosessiin kuuluu verbin lisäksi lausekkeita, jotka kuvaavat prosessin osallistujia (participants) sekä valinnaisesti myös olosuhteita (circumstances). (Halliday 2014: 220; Shore 1992: 210.) Prosessit jaetaan eri tyyppeihin kaikkien prosessin ilmentämien merkitysten ja myös kieliopillisten tekijöiden perusteella. Prosessien kolme pääluokkaa ovat materiaalinen, mentaalinen ja relationaalinen. (Halliday 2014: 213-214.) Karkeasti kuvattuna materiaaliset prosessit ilmentävät ulkoisia ja mentaaliset prosessit sisäisiä puolia prosessin toimijan kokemuksesta (Halliday 2014: 245). Relationaaliset prosessit taas kuvastavat asioiden ja havaintojen välisiä suhteita ja mahdollistavat näin asioiden luokittelun ja vertailun (mts. 214).

Päluokkien lisäksi Hallidayn (2014) jaottelussa on prosessien alaluokkia, jotka jakavat merkityksiä ja kieliopillisia piirteitä pääluokkien kanssa. Alaluokkiin kuuluvien prosessien analysoinnissa sovellan Shoren (1992) suomen kieleen tekemää luokittelua, jossa viestimiseen liittyvät kommunikaatioprosessit ovat mentaalisten prosessien alaluokka (mts. 274) ja olosuhteita sekä ominaisuuksia ilmaisevat eksistentiaaliset ja possessiiviset prosessit puolestaan relationaalisten prosessien alaluokka (mts. 248-2494; vrt. Halliday 2014: 213-214.) Olennaista oman tutkimukseni kannalta on se, että mentaaliset prosessit ja kommunikaatioprosessit viittaavat sisäiseen kokemukseen tai kokemuksen verbalisoituun muotoon (Shore 1992: 274) ja niiden avulla on mahdollista myös projisoida näitä kokemuksia (Halliday 2014: 253-254). Materiaalisissakin prosesseissa on erilaisia alaluokkia, ja vaikka prosessi nimensä puolesta viittaa konkreettiseen toimintaan, materiaalisiksi luokiteltavat prosessit voivat lisäksi viitata abstraktimpaan toimintaan (Halliday 2014: 243). Prosessia ilmaisevien verbien merkitysten analysoinnissa suhteutan huomioitani myös Anneli Pajusen (2001) verbisemanttiseen luokitteluun, joka on tehty nimenomaan suomen kielen pohjalta.

Toimijuuden näkökulmasta prosessityypit voidaan esittää niin, että materiaalisissa prosesseissa joku tai jokin tekee asioita, jotka ilmenevät toimijan ulkoisessa todellisuudessa (esim. Neuvostoliitto loi Itä-Eurooppaan satelliittivaltioita). Materiaalisen prosessin toimija on TeKIJ $\ddot{A}^{5}$ (actor), ja toiminnalla voi olla myös KOHDE (goal). Prototyyppisesti

4. Prosessien suomennoksista ks. Shore 2012b: 164.

5. Merkitsen prosessien osallistujatyyppien nimet kapiteelein selventääkseni niiden termimäisyyttä. 
materiaalinen prosessi kuvaa konkreettista tekoa. Mentaalisissa ja kommunikaatioprosesseissa toimijuus taas on sitä, että joku tai jokin ajattelee, tuntee tai sanoo asioita (esim. Puheessa Churchill kuvaa Neuvostoliiton toimia). Toimijana on tällöin кокIJA (senser) tai SANOJA (sayer). Koettava asia on puolestaan ILmiö (phenomenon) ja sanottava asia MAALI (target). Relationaalisissa prosesseissa ei niinkään ole kyse toiminnasta vaan olemisesta ja määrittelemisestä (esim. Yhdysvallat ja Neuvostoliitto olivat molemmat syyllisiä). Prosessin osallistujia nimitetään LuonnehditTAVAKsi (carrier) ja toimijaa määrittelevää prosessin osaa LuONNeHTIJAKsi (attribute; ks. Halliday 2014: 311). Prosessityypit ja niiden osallistujat voidaan jaotella vielä hienovaraisemmin (mp.), mutta tämän tutkimuksen ongelmanasettelun kannalta jaottelu päätyyppeihin ja edellä esitettyihin alatyyppeihin riittää osoittamaan eroja toimintojen esittämistapojen välillä.

Analyysiyksikköni on lause, eli olen analysoinut aineistoni jokaisen lauseen sen mukaan, mitä prosessityyppiä se edustaa. Tarkastelen lauseista sitä, millaisena toimintana historialliset tapahtumat esitetään, kuka toiminnan saa aikaan ja mikä on toiminnan mahdollinen kohde. Jotakin prosessityyppiä edustava lause voi toimia toisen prosessin osallistujana, jolloin SF-teoriassa puhutaan rankia vaihtaneesta lauseesta (ks. Shore 2012b: 161). Toisin kuin syntaktisemmin tekstiä lähestyvä Shore (2012b), analysoin toisen lauseen jäsenenä tai upotettuna lauseena olevien lauseiden prosessityypit erikseen, sillä lauseen syntaktinen suhde toiseen lauseeseen ei tämän tutkimuksen kysymyksenasettelun kannalta muuta lauseen ilmentämiä ideationaalisia merkityksiä. Prosessien osallistujien luokittelussa analyysiyksikköni on lauseke.

Aineistossani on yhteensä 832 prosessia. Näistä osa (52) on sellaisia, joissa mentaalisen prosessin KOKIJANA tai kommunikaatioprosessin SANOJANA on esseen kirjoittajaan viittaava toimija. Koska tutkimuskysymysteni selvittämiseksi fokuksessa ovat erityisesti tekstien ideationaalisia merkityksiä rakentavat valinnat, en analyysissani keskity kirjoittajan näkökulmaa koodaaviin prosesseihin ja sanastollis-kieliopillisiin piirteisiin. Tästä johtuen ainoastaan sivuan sellaisia piirteitä ja prosessityyppejä, joiden keskeinen merkitys on evidentiaalisuuden ja episteemisyyden ilmaisemisessa (mistä tieto on peräisin ja kuinka varmana tai epävarmana kirjoittaja esittää asian; ks. Halliday 2014: 677). Esimerkiksi seuraavan virkkeen alussa on johtolause, joka ilmaisee sekä tietolähteen (näiden dokumenttien perusteella) että kirjoittajan päättelyä ja tulkintaa verbiketjun voi päätellä välityksellä:

Näiden dokumenttien perusteella voi päätellä, että Stalin yritti kovasti peitellä aikeitaan aloittaa sota Yhdysvaltain Presidentiltä, sekä neuvostoliiton kansalaisilta. ${ }^{6}$

Historian tekstitaitojen kannalta kirjoittajan pättelyn ja tietolähteen ilmaukset ovat olennainen tekstien merkitystaso. Näiden interpersoonaisten merkitysten ilmaisemisen tavat ovat tekstissä kuitenkin hyvin moninaiset, ja niitä onkin tarpeen tarkastella systemaattisesti erikseen.

Esseissä on jonkin verran (120) verbiketjuja. Niissä ensimmäinen verbi on yleensä Pajusen (2001) luokittelun mukaisesti ei-primäärinen verbi eli verbi, jonka avulla

6. Kaikki aineistoesimerkit ovat alkuperäisessä kirjoitusasussaan. 
asiaintiloja kvalifioidaan ja suhteutetaan ja joka verbiketjussa usein edeltää asiaintilaa ilmaisevaa infinitiiviä (mts. 52). Verbiketjujen osana esiintyviä ei-primäärisiä verbejä ovat esimerkiksi mahdollisuutta ja pakkoa ilmaisevat saattaa ja voida sekä aspektuaaliset verbit alkaa, pyrkiä ja ryhtyä (mts. 52). Verbiketjuissa luokittelen prosessin primääriverbin mukaisesti, eli esimerkiksi lause Yhdysvallat pyrki estämään maiden siirtymistä kommunismiin edustaa materiaalista prosessia, koska estää on materiaalinen verbi. Palaan tähän tarkemmin alaluvussa 4.2 analysoidessani valtioiden toimijuuksia.

Yhdeksi keskeiseksi analyysissa tarkasteltavaksi kielelliseksi resurssiksi muodostuu kieliopillinen metafora. SF-teorian mukaan kullakin kieliopillisella kategorialla on omat, tunnusmerkittömät tehtävänsä, joissa kielellisen ilmaisun tehtävä ja muoto vastaavat toisiaan (Halliday \& Matthiessen 1999: 227). Esimerkiksi toimintaa ilmaistaan tunnusmerkittömästi verbillä ja asioita substantiivilla, jolloin kyseessä on kongruentti ilmaus. Kieliopillisella metaforalla tarkoitetaan SF-teoriassa sitä, että kielellisen ilmaisun tehtävä ja muoto eivät vastaa toisiaan. Tällainen inkongruentti ilmaus on esimerkiksi nominaalistus, eli toimintaa ilmaistaan verbin sijaan substantiivilla. (Karvonen 1991; Schleppegrell 2001: 443.) Nominaalistamisen avulla voidaan ilmaista toiminnasta aiheutuvia seurauksia tai antaa toiminnalle muita ominaisuuksia, mikä on keskeinen piirre sekä tieteellisessä kielessä (Halliday \& Martin 1993: 100) että koulujen oppikirjoissa (Karvonen 1995: 167), joista jälkimmäiset liittyvät tutkimieni esseiden tilannekontekstiin.

\section{Tutkimuksen aineisto}

Tutkimukseni aineistona on 23 esseevastausta, jotka on kirjoitettu eräässä keskisuuressa suomalaisessa lukiossa syksyllä 2015. Tekstit on kirjoitettu kansainvälisiä suhteita käsittelevän kurssin kurssikokeen yhteydessä, ja aineistona on yhden opetusryhmän kaikki esseevastaukset. Esseevastausten tilannekontekstiin ja tulkintakehykseen kuuluu monenlaisia tekstejä ja tekstikäytänteitä, kuten koulussa annettu opetus, opetuksessa käytetyt tekstit ja historian oppikirja, jotka voivat heijastua esseiden tavoissa esittää historiallista tietoa. Lisäksi huomioin tässä tutkimuksessa esseiden tehtävänannon ja siihen liittyvät dokumentit, joiden tavat konstruoida tietoa mahdollisesti vaikuttavat oppilaiden vastauksiin. Esseevastausten tehtävänanto kuuluu seuraavasti:

Mitä dokumenttien perusteella voi päätellä kylmän sodan aloittajasta? Perustele kantasi ja viittaa dokumentteihin, joihin tukeudut. Kirjoita pohtiva esseevastaus (n. 250-500 sanaa), jossa on selkeä kappalejako sekä aloitus- ja lopetuskappaleet. Muista määritellä ja ajoittaa keskeiset käsitteet.

Tehtävänanto vaikuttaa esseisiin muodostuviin ideationaalisiin merkityksiin rajaamalla käsiteltävän aiheen ja näkökulman (ks. Makkonen-Craig 2010). Tässä tehtävän-

7. (In)kongruentti ei siis tarkoita tässä samaa kuin syntaksin kuvauksessa, jossa puhutaan esimerkiksi subjektin ja predikaatin (in)kongruenssista (ISK 2004 \$1267). 
annossa pääkysymys ohjaa ottamaan kantaa kylmän sodan aloittajaan ja perustelemaan päätelmiä dokumenttien avulla. Tutkimusongelmani näkökulmasta kiintoisaksi muodostuu siis se, kuka tai mikä esseissä esitetään historiallisena toimijana sekä millaisena toiminta representoituu.

Kylmä sota käsittelee valtioiden poliittisten ja ideologisten erojen vastakkainasettelua, joten aihe on vahvasti poliittinen. Ohjeistuksen loppu muistuttaa koulussa kirjoitettavan esseen muodollisista piirteistä sekä yleisestä vaatimuksesta määritellä käytettävät käsitteet. Historian tiedonalan erityispiirteeksi voidaan katsoa se, että käsitteiden määrittelyyn kuuluu niiden ajoittaminen (ks. Rantala \& Veijola 2016: 271).

Tehtävään liittyy neljä vuosina 1946-1947 eli kylmän sodan alkuaikoina tuotettua dokumenttia, joista kolme on erilaisia poliittisia tekstikatkelmia ja yksi poliittinen pilapiirros (ks. verkkoliite). Yleiskuvauksena dokumenteista voi sanoa, että niissä korostuvat Stalinin ja Neuvostoliiton toimijuus sekä Euroopan tilanteen luonnehdinta. Dokumenttien keskeisenä aiheena toistuu se, miten kukin taho - valtio tai sen päämies suhtautuu kylmän sodan alkuaikoihin liittyviin tapahtumiin. Konkreettisia tapahtumia ei kuitenkaan kuvata tekoina, vaan ennemminkin dokumentteihin konstruoidaan henkilöiden suhtautumista muun muassa luonnehtimalla Euroopan tilannetta tai muiden historian henkilöiden esittämiä puheita.

Ensimmäinen dokumentti on katkelma Winston S. Churchillin Rautaesirippupuheesta, jossa Churchill puhuu Neuvosto-Venäjän toimista Itä-Euroopassa toisen maailmansodan lopussa. Puheen keskiössä on Euroopan tilanteen ja NeuvostoVenäjän toiminnan kuvaaminen. Toinen dokumentti on brittiläisessä Punch-lehdessä julkaistu E. H. Shephardin pilapiirros Trumanista ja Stalinista, jotka esitetään asiakkaita eli Euroopan valtioita itselleen houkuttelevina taksikuskeina. Kolmas dokumentti on kenraali Walter Bedell Smithin Yhdysvaltain presidentille lähettämä sähke, jossa hän kirjoittaa Stalinin kanssa käymästään keskustelusta. Sähkeessä korostuu se, mitä Stalin ajattelee Churchillin Rautaesirippu-puheesta. Neljäs dokumentti on Pravdalehdessä pian Rautaesirippu-puheen jälkeen julkaistu katkelma Josif Stalinin tekstistä, jossa hän puhuu toisen maailmansodan tapahtumista ja Neuvostoliiton toimista ItäEuroopassa.

Kylmää sotaa ja sen mahdollista aiheuttajaa ei mainita suoraan yhdessäkään dokumentissa. Dokumenteissa korostuu Neuvostoliiton ja etenkin Stalinin toiminnan ja suhtautumisen kuvaaminen. Dokumentit edustanevat tekstilajeiltaan jonkinlaisia poliittisten vallankäyttäjien puheita (Churchillin puhe ja Stalinin puhe Pravda-lehdessä), joissa on esimerkiksi tunteisiin vetoavaa retoriikkaa. Smithin sähkösanoma taas on jonkinlainen poliittinen raportti, joka on dokumenttiin johdattelevassa tekstissä luokiteltu huippusalaiseksi. Lisäksi mukana on poliittinen pilapiirros. Yksikään dokumentti ei siis tekstilajinsa puolesta edusta vastaustekstin kaltaista erittelevää asiatekstiä.

\section{Ihmisten toiminnan rakentuminen esseevastauksissa}

Analysoin tässä luvussa sitä, minkälaisena ihmisten toiminta representoituu esseissä. Aloitan prosesseista, joissa toimijoiksi on nimetty yksilöityjä historian henkilöitä. Sen 
jälkeen siirryn prosesseihin, joissa toimijuus annetaan ihmiskollektiiveille, kuten valtioille. Pohdin luvussa näiden toimijoiden, historian tiedonalan kielen ja tehtävänantoon liittyvien dokumenttitekstien suhdetta.

\subsection{Yksilöidyt ihmiset toimijoina}

Historian henkilöt muodostavat esseissä yhden keskeisen toimijatyypin. Kaikki esseiden henkilötoimijat ovat dokumenteissa esiintyviä henkilöitä tai dokumenttien tuottajia, joista useimmin nimeltä mainitaan Stalin; toiseksi eniten nimellä viitataan Churchilliin. Sen sijaan sähkösanoman kirjoittaja kenraali Walter Bedell Smith mainitaan harvemmin, ja pilapiirroksen tuottamiseen viitataan puolestaan usein passiivilla ilman mainintaa piirtäjästä. Stalin ja Churchill ovatkin molemmat historiallisesti merkittäviä valtioiden päämiehiä ja oletettavasti opiskelijoille tuttuja henkilöitä historian opetuksesta. Heidän suhteestaan puhutaan myös sähkösanomassa, jossa pääasiallisesti referoidaan Stalinin reaktioita Churchillin pitämään Rautaesirippu-puheeseen. Stalinin tuntemukset ja ajatukset ovat siis esillä lähes kaikissa dokumenteissa.

Tämän tutkimuksen näkökulmasta henkilötoimijaiset prosessit muodostavat esseisiin kiinnostavia ideationaalisia merkityksiä, vaikka yhtä aikaa samat prosessit tuottavat myös interpersoonaisia merkityksiä, sillä ne esimerkiksi osoittavat tiedon lähteen tai näkökulman (ks. Halliday 2014: 677). Tavallisimmin henkilötoimijat ovat kommunikaatioprosessien SANOJINA sekä jonkin verran mentaalisten prosessien KOKIJOINA, mikä johtunee siitä, että näiden prosessien avulla voidaan esittää projektioita dokumenttien sisällöstä (mts. 253).

Lähes kaikissa esseissä viitataan kaikkiin neljään dokumenttiin, ja dokumenteista nostetaan esille yleensä samankaltaisia asioita. Seuraavassa esimerkissä puhutaan Rautaesirippu-puheen sisällöstä:

(1) 1. dokumentin mukaan Winston S. Churchill kritisoi Rautaesirippupuheessaan Stalinin toimia toisen maailmansodan jälkeen.

Esimerkissä 1 Churchill on SANOJANA kommunikaatioprosessissa kritisoida, joka referoinnin lisäksi kertoo Churchillin asenteen puheenaihetta kohtaan. Kritisoinnin kohteena eli MAALINA on Stalinin toimet, vaikka Rautaesirippu-puheessa Churchill ei mainitse Stalinia nimeltä, vaan puheen ainoana nimettynä toimijana on Neuvosto-Venäjä. Monissa esseissä kuitenkin puhutaan Neuvostoliiton toiminnasta Stalinin toimintana, mikä johtunee siitä, että Stalinin sanomisia esitetään kahdessa muussa dokumentissa. Dokumentteja siis tulkitaan suhteessa toisiinsa, mutta samalla korostuu myös Stalinin henkilökohtainen merkitys Neuvostoliiton päätöksenteossa. Stalinin toimet on kieliopillinen metafora ja abstrakti teonnimi, jossa varsinaiset toimet jäävät yksilöimättä. Esimerkissä keskeiseksi muodostuu siten Churchillin asennoituminen eikä niinkään konkreettiset teot ja tapahtumat. Esimerkin 1 kaltaisissa kommunikaatioprosesseissa ei siis ole kyse vain dokumenttiin viittaamisesta, vaan Churchillin puhe esitetään historiallisena tapahtumana, josta keskeiseksi nostetaan hänen suhtautumisensa Stalinin tai Neuvostoliiton toimiin. 
Stalin esiintyy esseevastauksissa paljon oletettavasti siitä syystä, että hänet mainitaan neljästä dokumentista kahdessa ja hän on itse yhden kirjoittaja; ainoastaan Churchillin puheessa häneen ei viitata suoraan. Kommunikaatioprosesseista monet esittävätkin Stalinin sanomisia ja suhtautumista: esseissä Stalin muun muassa $s a-$ noo, puhuu, kertoo ja selittää mutta usein myös tulkinnallisemmin ilmaistuna syyttää, korostaa, vihjaa ja leimaa (referointiverbin valinnasta ks. ISK $2004 \$ 1476$ ). Esseevastauksiin rakentuu siis tulkintoja dokumenteissa esiintyvien henkilöiden suhtautumisesta. Tulkinnallisuus korostuu erityisesti mentaalisissa prosesseissa, jotka esittävät inhimillisten toimijoiden sisäistä kokemusta (Halliday 2014: 253), kuten seuraavassa esimerkissä:

(2) Stalinia tällainen raju arvostelu ärsytti ja hän koki esimerkiksi Churchillin puheen hyökkäyksenä Neuvostoliittoa vastaan - -

Esimerkin 2 molemmat prosessit, ärsyttää ja kokea, kuvastavat KOKIJANA olevan Stalinin tunteellista reaktiota. Molemmissa prosesseissa ILmı̈̈ıN̈̈ on kieliopillinen metafora, joka ikään kuin pakkaa puhetapahtuman substantiiviksi: ensimmäisessä prosessissa puhetta nimitetään arvosteluksi, jolle voidaan nominaalistamisen myötä antaa kirjoittajan arviota kuvastava määrite raju. Jälkimmäisessä prosessissa taas puhetta nimitetään hyökkäykseksi. Ensimmäinen prosessi ärsyttää on tunnekausatiivilause, joka voitaisiin tulkita myös materiaaliseksi prosessiksi (ks. Shore 1992: 267-268), mutta tässä olennaista on lauseen sisältämä mentaalinen merkitys. Esimerkki kuvastaa sitä, kuinka kieliopillinen metafora on keskeinen arvioivan tekstin kielellinen resurssi (ks. Coffin 1997: 217).

Esseissä puhutaan myös ensimmäisen dokumentin kirjoittajan eli Churchillin tuntemuksista:

(3) Churchill ei niinkään ollut huolissaan sosialismin leviämisestä Itä-Euroopassa, mutta hän oli huolissaan Neuvostoliiton vallan kasvusta kyseisillä alueilla - - .

Esimerkissä 3 mentaalinen prosessi olla huolissaan toistuu molemmissa lauseissa, joissa кOKIJANA on Churchill. Prosessin ILMiö on ilmaistu nominaalistuksena (sosialismin leviäminen, Neuvostoliiton vallan kasvu), mikä vie toimijoita taka-alalle (ks. Karvonen 1991). Leviämisen ja kasvun aiheuttajien tai tapahtumien konkreettisen ilmenemismuodon sijaan korostuu siten kirjoittajan tulkinta Churchillin suhtautumisesta.

Esseevastausten tehtävänanto edellyttää dokumenttien avulla perustelemista ja dokumentteihin viittaamista. Dokumenttien perusteella tehtävät päätelmät taas kytkeytyvät dokumenttien tuottajien motiivien, ajatusten ja tuntemusten tulkitsemiseen. Tapahtumien selittäminen historiallisesti merkittävien henkilöiden sanomisen, suhtautumisen ja tunteiden näkökulmasta heijastaa esseevastausten tehtävänantoa, jossa pyydetään perustelemaan kantoja dokumenttien avulla. Joissakin esseissä henkilökeskeinen selittäminen korostuu: Churchillin Rautaesirippu-puheen sisältö saatetaan esittää juuri Staliniin kohdistuvana, vaikka häntä ei puheessa henkilöidä, ja Stalinin sanomiset saatetaan esittää voimakkaasti hänen henkilökohtaisena suuttumuksenaan. Neuvosto- 
liiton toiminnan henkilöiminen pelkästään Staliniin tai ylipäätään henkilötoimijuus voi kieliä siitä, että kirjoittaja pidättäytyy tiukasti dokumenteissa eikä laajenna tulkintojaan rakenteellisemmalle tasolle (ks. Coffin 2006: 6).

Esseevastauksissa on siis paljon kommunikaatio- ja mentaalisia prosesseja, jotka eivät toimi ainoastaan dokumenttia referoivina johtolauseina: dokumenteissa esiintyvien henkilöiden tai dokumentin tuottajien sanomiset ja suhtautuminen esitetään esseissä historiallisina tapahtumina. Myöskään pohjadokumenteissa ei puhuta henkilöiden tekemistä konkreettista teoista vaan kuvataan valtioissa vallitsevia tilanteita ja puhutaan erityisesti Stalinin suhtautumisesta ja sanomisista. Sanominen ja suhtautuminen ovat toimintoina abstrakteja samoin kuin esimerkeissä olevien prosessien ILмIÖт ја MAALIT sekä OLOSUHTEET, jotka ilmaistaan usein kieliopillisen metaforan avulla. Esseevastauksissa esitettävien asioiden abstraktius näkyy myös seuraavissa esimerkeissä, joissa käsittelen valtioiden toimijuutta.

\subsection{Valtiot ja ihmisjoukot toimijoina}

Yksilöityjen ihmisten lisäksi esseissä toimijoiksi nimetään ihmisjoukkoja, valtioita ja kylmän sodan osapuolia (länsi, suurvallat, saksalaiset). Valtioiden toiminnasta puhuminen liittää esseet muihin historian teksteihin, kuten oppikirjoihin (ks. Väisänen 2005: 136-137). Dokumenteissa puhutaan kylmän sodan osapuolista sekä Euroopan maista ja kaupungeista mutta pääsääntöisesti vain prosessien olosuhteissa (esim. Hän vihjasi tämän puheen ja monien vastaavien tapahtumien viittaavan selkeään neuvostovastaiseen suuntaukseen Iso-Britanniassa ja Yhdysvalloissa.) tai luonnehdittavina relationaalisissa prosesseissa (esim. Tuon linjan takana ovat vanhojen Keski- ja Itä-Euroopan maiden pääkaupungit.). Neuvosto-Venäjä ja Neuvostoliitto esiintyvät kahdessa dokumentissa myös toimijoina mutta Yhdysvallat, Iso-Britannia tai länsi eivät kertaakaan. Tässä valossa on yllättävää, että näistä Yhdysvallat ja länsi esiintyvät usein toimijoina opiskelijoiden esseevastauksissa. Valtioita ei niissä esitetä myöskään ensisijaisesti maantieteellisinä alueina vaan kylmään sotaan liittyneen poliittisen valtataistelun osapuolina, mikä yhdistää esseet jonkinlaiseen poliittiseen diskurssiin. Analysoin seuraavien esimerkkien avulla, miten tällainen representaatio syntyy.

Poliittista diskurssia rakentaa se, että prosesseissa puhutaan kylmän sodan osapuolten voimasuhteista ja ideologioiden vastakkainasettelusta:

(4) Länsivallat - - pyrkivät kuitenkin kasvattamaan valtaansa muissa maissa perusteenaan kommunismin ehkäiseminen.

Esimerkissä 4 kerrotaan länsivaltojen toiminnasta (länsivallat pyrkivät). Toimintaa perustellaan prosessin oLOSUHTEISSA kieliopillisen metaforan avulla ilmaistulla poliittisella linjauksella (kommunismin ehkäiseminen). Esimerkin prosessissa контEENA on esseille tyypillisesti merkitykseltään varsin abstrakti poliittinen käsite valta. Toinen esimerkin edustama esseevastausten tyypillinen piirre on se, että siinä prosessi muodostuu verbiliitosta, jonka ensimmäinen osa (pyrkiä) on luonteeltaan mentaalinen ja jälkimmäinen osa (kasvattaa) perusmerkitykseltään konkreettista tekoa kuvaava verbi. 
Samaan tapaan valtiot esitetään esseissä toimijoina prosesseissa, jotka muodostuvat yrittää tehdä- ja koettaa tehdä -rakenteista. Pajusen (2001: 52) mukaan verbien pyrkiä, yrittää ja koettaa kaltaiset verbit ovat sekundaarisia verbejä, jotka kuvastavat usein asennetta tai suhtautumista asiantilan sijaan. Edeltävissä esimerkeissä ne korostavat valtioiden intentioita lopputuloksesta huolimatta ja rakentavat niistä kuvaa ihmisistä koostuvina päätöksentekoeliminä, mikä liittää tekstin poliittiseen diskurssiin. Prosessit myös luovat kuvaa kylmästä sodasta aikakautena, jossa vallitsevana olosuhteena on ennemminkin uhka kuin konkreettinen toiminta.

Länsivalloista Yhdysvallat esitetään myös avustavassa ja tilannetta korjaavassa roolissa:

(5) - - Yhdysvaltojen tuli taata muille valtioille vapaus ja mahdollisuus demokratiaan.

Esimerkissä 5 takaamisen контеENA on kieliopillisista metaforista muodostuva $v a$ paus ja mahdollisuus demokratiaan, jossa täydennyksenä demokratia viittaa ideologisen merkityksensä puolesta ajattelulliseen tai poliittiseen vapauteen ja mahdollisuuteen. Esimerkissä nesessiivinen tuli taata korostaa Yhdysvaltojen velvollisuutta ja samalla myös personoi Yhdysvaltoja. Kuten aiemmin mainitsin, länsi ja Yhdysvallat eivät esiinny dokumenttien toimijoina, joten esimerkkien 4 ja 5 kaltaiset prosessit ilmaisevat kirjoittajalla olevaa historian kontekstitietoa ja liittynevät dokumenteissa kuvattavien henkilöiden sanomisten tulkitsemiseen.

Valtiot ovat yleisimmin toimijoina materiaalisissa prosesseissa, mutta esimerkin 5 kaltaisesti apuverbi voi korostaa prosessin mentaalista ulottuvuutta. Usein materiaaliset prosessit ovat myös seuraavien esimerkkien kaltaisia eli ne viittaavat käyttäytymiseen ja kontrollointiin:

(6) - - Venäjä yrittää propagandallaan sytyttää vihaa ja painostaa kansojaan sotaan.

(7) Stalinin mielestä Britit ja USA uhkailevat Neuvostoliittoa - -.

Esimerkissä 6 ensimmäinen prosessi on aiemmin käsitellyn esimerkin 5 kaltainen, eli prosessissa yrittää sytyttää on sekä mentaaliseen että materiaaliseen toimintaan viittaavat verbit ja KOHTEENA on viha. Esimerkin 6 toinen prosessi painostaa samoin kuin esimerkin 7 prosessi uhkailla viittaavat käyttäytymiseen ja lähenevät merkitykseltään myös kommunikaatioprosesseja: painostaminen ja uhkailu voivat toteutua myös verbaalisesti. Esimerkin 7 olosuhteissa johtoilmaus Stalinin mielestä eksplikoi kyseisen asian olevan dokumenteista tehtävää tulkintaa. Tähän palaan tuonnempana käsiteltyäni valtioita mentaalisten prosessien toimijana.

Henkilötoimijoiden tapauksessa kommunikaatioprosessit rakentavat kuvaa kylmästä sodasta poliittisena konfliktina, jossa valtioiden päämiesten ajattelu ja sanomiset ovat keskeisiä. Valtiot eivät juuri ole toimijoina kommunikaatioprosesseissa, mutta esseissä esitetään jonkin verran valtioiden suhtautumista mentaalisten prosessien avulla: 
Neuvostoliitto näki että länsimaat eivät arvostaneet niiden sotauhrauksia toisessa maailmansodassa ja huomasi Länsimaiden neuvosto-vastaisuuden.

Esimerkissä 8 on kolme mentaalista prosessia, joista kahdessa кокIJANA on Neuvostoliitto ja yhdessä länsimaat. Prosessi nähdä on esimerkki siitä, kuinka mentaalisen prosessin avulla voidaan projisoida ajatuksia ja kokemuksia: prosessin ILMIÖNÄ on että-lause, jossa kerrotaan länsimaiden suhtautumisesta Neuvostoliiton toimia kohtaan. Kahden muun prosessin ILMIöт, niiden sotauhraukset ja länsimaiden Neuvostovastaisuus, on muodostettu kieliopillisen metaforan avulla eli verbi uhrata ja adjektiivi neuvostovastainen on nominaalistettu. Näin ne voivat saada genetiivimääritteekseen valtion. Esimerkin 8 kaltaiset valtioiden tuntemuksia tulkitsevat prosessit voivat heijastella Pravda-lehdessä ilmestynyttä Stalinin puhetta. Puheessa Stalin kertoo Neuvostoliiton suhtautumisesta mentaalisissa prosesseissa, joissa Neuvostoliitto on KOKIJANA.

Mentaaliset prosessit korostavat sitä, että valtiot edustavat niiden taustalla vaikuttavia yksilöimättömiä ihmisryhmiä, kuten kansalaisia, sotilaita, hallitusta ja päämiehiä. Toisaalta se, että valtiot esitetään hyvin inhimillisinä kokijoina, voi kummuta myös pohjadokumenteista tehtävistä tulkinnoista: Kaikissa esseissä eritellään dokumenttien kirjoittajien sanomista ja suhtautumista, mikä näkyy erityisesti alaluvussa 4.1 erittelemissäni henkilötoimijaisissa kommunikaatio- ja mentaalisissa prosesseissa. Kun esseevastauksessa SANOJAKSI tai KOKIJAKSI esitetäänkin dokumenttien erittelyn yhteydessä valtio, voidaan ajatella, että kirjoittajan tekemät tulkinnat historian henkilöiden välisistä suhteista ikään kuin laajennetaan koskemaan valtioiden suhteita. Tämä on ilmeistä silloin, kun prosessiin esimerkin 7 kaltaisesti liittyy suoraan dokumenttiin viittaava johtoilmaus (Stalinin mielestä), mutta tulkinnallisempaa esimerkin 8 kohdalla. Tässä analyysissa en keskity evidentiaalisuuteen eli siihen, mistä tiedon ilmaistaan olevan peräisin. Esseiden voidaan kuitenkin analyysini perusteella tulkita kaiuttavan pohjadokumentteja ja yhdistävän dokumenttien analyysiin historian tiedonalan sekä poliittisen diskurssin kielellistämisen tapoja eli sitä, että ihmisten sijaan valtiot representoidaan päätöksiä tekevinä ja toiminnasta vastuussa olevina tahoina (ks. Halldén 1998: 133).

Tehtävänannon pääkysymys kylmän sodan aloittajasta heijastunee esseevastauksien toimijuuksissa siinä, että toimijuus annetaan pääasiassa valtaapitäville tahoille eli valtioiden päämiehille ja suurvalloille. Se, että toimijuus on valtaapitävillä, voidaan ajatella tyypilliseksi ainakin oppikirjojen historian diskurssille, kun taas vaihtoehtoisempana historiakuvauksena voitaisiin pitää sellaista, jossa näkökulma on tavallisilla kansalaisilla tai sorretuilla valtioilla (esim. Löfström \& Hakkari 2003: 319). Jos dokumenteissa olisi mukana myös kansalaisten kertomuksia tai Itä-Euroopan alistettujen maiden näkökulmasta esitettyjä dokumentteja, esseisiin voisi muodostua toisenlaisia toimijuuksia. Luultavasti tehtävänannon pääkysymys olisi siinä tapauksessa muotoiltu toisin. Kiinnostavaa on myös se, että länsivalloista toimijuus annetaan yleensä Yhdysvalloille eikä juurikaan Churchillin edustamalle Isolle-Britannialle, vaikka Churchill onkin Rautaesirippu-puheen kirjoittaja. Esseiden toimijat eivät siis kumpua täysin suoraan dokumenteista, vaan tapahtumien ilmaiseminen Yhdysvaltojen ja länsivaltojen toimijuuden avulla voi kertoa myös siitä, mitä historian opetuksessa on kerrottu Yhdysvaltojen roolista kylmässä sodassa, eli heijastella kirjoittajan kontekstitietoa aiheesta. 


\section{Toimijuus tapahtumien ja kausaalisuhteiden kuvauksessa}

Historian henkilöiden ja valtioiden toimintaa ilmaisevien prosessien lisäksi esseissä on prosesseja, joissa varsinainen toimija tai ainakin inhimillinen toimija jää taka-alalle. Tällöin prosessissa korostuvat tapahtumat ja asioiden väliset suhteet. Historiallisten tapahtumien kuvaus korostuu silloin, kun kylmän sodan osapuolten toimintaan viitataan passiivin avulla:

(9) Marshall-apua annettiin halukkaille länsi-Euroopan valtioille ja sitä tarjottiin myös Itä-Euroopan valtioille.

(10) Otettiin käyttöön patoamispolitiikka, eli Yhdysvallat yritti rajata kommunismin mahdollisimman pienelle alueelle.

Molemmissa esimerkeissä passiivi viittaa asiayhteyden perusteella Yhdysvaltoihin. Prosessit antaa ja tarjota samoin kuin ottaa käyttöön ovat materiaalisia prosesseja, joiden контеena esimerkissä 9 on historiallinen käsite Marshall-apu ja esimerkissä 10 patoamispolitiikka. Esimerkissä 10 ensimmäinen lause ja sen sisältämä käsite patoamispolitiikka kirjoitetaan auki eli-konjunktiolla alkavassa lauseessa. Siinä Yhdysvallat esitetään TEKIJÄKsI prosessissa, jossa verbi yrittää ilmaisee aikomusta ja verbi rajata konkreettista toimintaa, kuten myös alaluvussa 4.2 analysoimissani valtioiden toimintaa kuvaavissa materiaalisissa prosesseissa. Passiivin voidaan ajatella vievän toimijan taka-alalle (ISK $2004 \$ 1313$ ), ja passiivi voikin heijastella politiikan kielelle ominaista tapaa esittää päätökset tapahtuviksi ilman yksilöityjä vastuullisia toimijoita (ks. Heikkinen 1999: 146147). Toisaalta passiivia voidaan pitää yleisemmin abstraktin ja teknisluonteisen tekstin tuntomerkkinä (Halliday \& Matthiessen 1999; Karvonen 1995: 167).

Esimerkit 9 ja 10 heijastelevat esseevastausten tilannekontekstin alaan (field) kuuluvia muita historian tekstejä, sillä dokumenteissa ei puhuta Marshall-avusta tai patoamispolitiikasta, jotka kuitenkin ovat selvästi poliittiseen historiaan kuuluvia käsitteitä. Käsitteiden merkityksen selittäminen ja tilanteiden kuvaaminen muistuttavat oppikirjadiskurssia, jolle on tyypillistä asioiden avaaminen (Shore 2012b: 169) ja johon siten myös rakentuu asiaa vähemmän ymmärtävä lukija (ks. Karvonen 1995: 217). Vastaustekstilajin aktuaalinen lukija on kuitenkin opettaja, joka yleensä hallitsee asiasisällön kirjoittajaa paremmin. Käsitteiden topikalisoiminen ja selittäminen liittyvätkin vastaustekstin funktioon, jossa kirjoittaja pyrkii osoittamaan hallitsevansa tehtävänannossa kysyttävän asian. Sitä voidaan pitää kirjoittajalla olevana historian kontekstitietona eli opetuksen ja muiden lähteiden myötä omaksuttuna tietona (ks. Rantala \& Veijola 2016). Esseisiin siis sisältyy sellaisten historiallisten tilanteiden kuvausta, joka ei kumpua ilmiselvästi pohjateksteinä olevista dokumenteista.

Historiallisten tilanteiden kuvailuun liittyy historian diskurssissa olennaisesti tapahtumien ajoittaminen (Seixas \& Morton 2013; Coffin 2006):

(11) Yhdysvaltojen Hiroshiman ja Nagasakin ydinpommit päättivät toisen maailmansodan 1940-luvulla. 
Esimerkissä 11 ydinpommien tiputtaminen ajoitetaan vuosiluvun lisäksi ajankohtaan viittaavan historian käsitteen, toisen maailmansodan, avulla. Tällaisia ajanjaksoja niputtavia käsitteitä Henry Walsh (1974) nimittää kolligatorisiksi käsitteiksi, sillä niissä historian tiedonalan käsitteeseen yhdistyy usein monenlaista tietoa tapahtumista ja ajankohdista. Esimerkissä 11 prosessi päättää kuvaa muutosta. Prosessin TEKIJÄNÄ on historiallista tapahtumaa kuvaava lauseke Yhdysvaltojen Hiroshiman ja Nagasagin ydinpommit. Muutoksen ja jatkuvuuden ymmärtäminen on yksi historian opetuksen keskeistä tavoitteista (Seixas \& Morton 2013; Rantala \& Ahonen 2015), ja tämän ymmärryksen ilmaisemista käsittelen myös seuraavissa esimerkeissä. Ydinpommeista ei ole myöskään puhetta dokumenteissa, joten esimerkki kaiuttaa taas kirjoittajalla olevaa historian kontekstitietoa ja yhdistää esseevastauksen historian tiedonalan muihin teksteihin.

Henkilö- ja valtiotoimijoiden yhteydessä samoin kuin edellä esittelemissäni esimerkeissä prosessit kuvaavat usein merkitykseltään abstrakteja tapahtumia, kuten henkilöiden ja valtioiden tuntemuksia tai reaktioita poliittisiin suhteisiin. Abstraktiuteen liittyy keskeisesti kieliopillinen metafora, jonka avulla henkilö- ja valtiotoimijoiden yhteydessä ilmaistaan prosessien kohteita ja olosuhteita. Kieliopillisen metaforan avulla tekstissä on myös mahdollista tematisoida tapahtumia, jolloin lauseen verbillä voidaan ilmaista tapahtumien välisiä kytköksiä (Karvonen 1995: 168, 173-174). Tapahtumien tematisointi liittyy erityisesti tekstuaaliseen metafunktioon, sillä sen avulla tekstissä mahdollisesti aiemmin kongruentisti ilmaistut tapahtumat voidaan pakata teonnimiksi ja siten ikään kuin nostaa tekstin abstraktiotasoa. Tämä on tyypillistä oppikirjatekstille (Karvonen 1995: 168-169).

Seuraavissa esimerkeissä kuvataan historiallisissa olosuhteissa tapahtuvaa muutosta, ja tapahtumien aiheuttaja ja inhimillinen toimija on viety edeltäviä esimerkkejä selvemmin taka-alalle:

(12) Aluehallinnollinen kilpailu johti kylmän sodan suuruuspyrkimyskilpaan.

Esimerkissä 12 TEKIJÄ aluehallinnollinen kilpailu on muodostettu kieliopillisen metaforan avulla, kun kilpailla-verbistä on nominaalistettu teonnimi kilpailu. Prosessin конTEENA oleva käsite suuruuspyrkimyskilpa rakentuu kolmesta kieliopillisesta metaforasta, joiden avulla kuvataan maiden pyrkivän suuremmaksi kuin toinen ja kilpailevan keskenään vallasta. Esimerkissä 11 kausaalisuhde on muodostettu päättää-verbin avulla, joka ilmaisee esimerkin 12 johtaa-verbiin verrattuna punktuaalisempaa tapahtumaa: historiallisissa olosuhteissa tapahtuva muutos vaikuttaa äkillisemmältä ja ajallisesti rajatummalta. Sen sijaan johtaa-prosessi vaikuttaa pitkäkestoisemmalta eli on merkitykseltään duratiivinen. (ISK $2004 \$ 1505-1506$.) Molemmissa esimerkeissä seuraus on esitetty resultatiivisesti muutokseen johtavana.

Seuraavissa esimerkeissä niin ikään korostuu muutos mutta ei yhtä ehdottomasti kuin edeltävissä esimerkeissä:

(13) Kommunismin pakollinen levittäminen aiheutti myöhemmin konflikteja Aasiassa ja ihmishenkien menetyksiä. 
(14) Kylmän sodan alkamiseen vaikutti se, että Neuvostoliitto sekä USA eivät luottaneet toisiinsa.

Molemmissa esimerkeissä prosessi ilmaisee kahta hieman erilaista syy-seuraussuhdetta. Esimerkissä 13 prosessin aiheuttaa конDE on ilmaistu rajaamattomana (konflikteja). Kommunismin levittämisellä esitetään siis olevan seurauksia, mutta tapahtumien välinen kausaalinen suhde ei ole väistämätön. Esimerkin 13 TEKIJÄ on nominaalistus, kun taas esimerkissä 14 tekijänä on se-pronomini ja sitä määrittävä että-lause ${ }^{8}$ prosessissa vaikuttaa. Myös конDE (kylmän sodan alkaminen) on ilmaistu nominaalistuksena. Verbin vaikuttaa rakentama kausaalisuhde TEкIJ̈̈N ja контEEN välillä ei ole edellisiin esimerkkeihin verrattuna yhtä ehdoton ja ajallisesti selvärajainen: Neuvostoliiton ja USA:n keskinäinen epäluottamus nimetään yhdeksi sodan alkuun vaikuttaneeksi tekijäksi muttei sen yksioikoiseksi aloittajaksi. Esimerkkien tavat esittää kausaalisuhteita kuvastavat sitä, kuinka historiatiedon rakentumisessa ei ole formaaleja loogisia syy-seuraussuhteita, vaan kausaalisuuteen liittyy hyvin usein tulkinnallisuutta (Martin 2002: 97-98).

Edellisissä muutosta ja kausaalisuhteita ilmaisevissa esimerkeissä on kaikissa jonkinlainen toimintaa ja tapahtumia kieliopillisen metaforan tai lauseen avulla ilmaiseva TEKIJÄ sekä toiminnan seurausta kuvaava KOHDE. Niissä myös prosessia ilmaiseva verbi on tekoverbi toisin kuin seuraavissa esimerkeissä (15-18), joissa prosessin keskiössä oleva muutosverbi ilmaisee tilanmuutosta teon sijaan (ks. Pajunen 2001: 54):

(15) Joka tapauksessa jatkuvan kostokierteen seurauksena syntyi kauhun tasapaino - - .

Esimerkissä 15 kausaalisuutta ilmaistaan prosessin OLOsuHtEIssa substantiivilla ( $\mathrm{seu}$ rauksena), minkä Martin (2002: 96) toteaa olevan tyypillistä historian kielelle sen sijaan, että kausaalisuutta tuotaisiin esiin konjunktioiden avulla. Esimerkissä ilmaistaan muutos historiallisissa olosuhteissa prosessilla syntyä, joka kuvastaa tapahtumaa teon sijaan (Pajunen 2001: 52).

Myös seuraavissa esimerkeissä kuvataan historiallisia tapahtumia, mutta näissä ei esitetä minkäänlaista kausaalista suhdetta:

(16) Kylmä sota alkoi toisen maailmansodan jälkeen ja loppui Neuvostoliiton hajoamiseen 1900-luvun lopussa.

(17) [- - kylmä sota] puhkesi Euroopassa heti toisen maailmansodan jälkeen.

(18) [- - kylmä sota] lähinnä vain kehittyi Yhdysvaltojen ja Neuvostoliiton välille.

Prosessit lähenevät merkitykseltään relationaalisia prosesseja, sillä ne liittävät kylmän sodan käsitteeseen ominaisuuden, joka historian tiedonalan luonteen ja essei-

8. SF-teoriassa tällaista prosessin osallistujana toimivaa toista lausetta kutsutaan rankia vaihtaneeksi lauseeksi (ks. Shore 2012b: 161). 
den tehtävänannon mukaisesti kontekstualisoi käsitteen ajallisesti (ks. Coffin 2006). Käsitteen määrittelyn kannalta esimerkit kuitenkin antavat kylmästä sodasta keskenään hieman erilaisen kuvan: Esimerkissä 16 prosessit alkaa ja loppua eivät rajaa tapahtumaa ajallisesti yhtä selvästi kuin esimerkissä 17 prosessi puhjeta, joka esittää sodan alkamisen selvärajaisena ja äkillisenä punktuaalisena tapahtumana. Esimerkissä 18 taas on kyse duratiivisesta prosessista, jonka ajalliset rajat ovat muita esimerkkejä epämääräisemmät. (Ks. ISK $2004 \$ 1505-1506$.) Prosessien olosuhteissa ei kerrota syytä kylmälle sodalle vaan rajataan sota ajallisesti. Käsite siis määritellään suhteessa toisiin historiallisiin tapahtumiin (toisen maailmansodan jälkeen, Neuvostoliiton hajoaminen) tai jonkin muun ajallisen määritteen avulla (19oo-luvun lopussa). Esimerkin 18 olosuhteissa kuvataan ikään kuin tapahtuman poliittista sijaintia (Yhdysvaltojen ja Neuvostoliiton välille).

Esimerkeissä 15-18 kuvataan syy-seuraussuhteen sijaan eräänlaisia eksistentiaalisia muutoksia historiallisissa olosuhteissa eli toisin sanoen tapahtumia ennemmin kuin tekoja (ks. Pajunen 2001: 120). Prosesseilla on myös käsitettä ajallisesti määrittelevä tehtävä, mikä on oleellista historian tekstitaidoille ja minkä voidaan ajatella ilmaisevan myös kirjoittajalla olevaa historian kontekstitietoa, sillä kylmän sodan käsitettä ei mainita eikä määritellä oheisdokumenteissa. Toisin kuin luvussa 4 edeltävissä esimerkeissä toiminnan esittäminen rakentuu siis ennemminkin kronologisuuden ja kausaalisuuden kuin historian toimijoiden intentioiden varaan (ks. myös Väisänen 2005: 132).

Esseevastauksissa historiallisia käsitteitä samoin kuin valtioita kuvataan paljon myös sellaisten relationaalisten prosessien avulla, joissa ei ole varsinaista toimijaa. Niissä ilmaistaan prosessin osallistujien olemista suhteessa johonkin toiseen asiaan ennemminkin kuin toimintaa tai tapahtumista. Relationaalisissa prosesseissa suhteen osapuolet ovat Luonnehdittava ja Luonnehtija (Halliday 2014: 311). Prosesseilla voidaan näin ollen antaa asioille ominaisuuksia ja arvioida niitä suhteessa toisiinsa. Toiminta on tästä johtuen usein nominaalistettu, jotta sitä voidaan kuvailla ja arvioida. Tyypillisimmin relationaalinen suhde esitetään olla-verbillä (Halliday 2014: 262). Myös relationaaliset prosessit yhdistävät esseetekstit niin oppikirjakieleen (vrt. Karvonen 1995: 177) kuin tieteelliseen kieleen (Halliday \& Matthiessen 1999).

Seuraavassa esimerkissä otetaan kantaa tehtävänannon kysymykseen kylmän sodan aloittajasta:

(19) Yksi kylmän sodan kehittymisen syistä oli myös Yhdysvaltojen pelko kommunistisen aatteen leviämisestä.

Relationaaliselle prosessille ominaisesti esimerkin 19 keskiössä on olla-verbi, jonka välityksellä kuvataan asioiden välistä suhdetta. Esimerkissä toiminta on ikään kuin pysäytetty kieliopillisten metaforien avulla (kehittyminen, leviäminen), ja siinä keskitytään analysoimaan toimintojen ja tuntemusten välisiä suhteita: LuONNEHTIVA osallistuja nominaalistaa tunnetta ja toimintaa (pelko, leviäminen) ja personifioi valtiota liittämällä tunteen Yhdysvaltoihin. LuONNEhditTAVANA on niin ikään kieliopillinen metafora yksi kylmän sodan kehittymisen syistä. Sisällöllisesti esimerkissä esitetään myös arvio syy-seuraussuhteesta, kun syyksi esitetään pelko, joka vaikuttaa siihen, että kylmä sota 
kehittyi. Kiinnostavaa on se, että edellä käsitellyissä esimerkeissä monet kieliopilliset metaforat eivät kongruentistikaan ilmaise konkreettista toimintaa vaan muutosta (alkaa, seurata, kehittyä). Tämä johtunee käsiteltävän aiheen poliittisesta luonteesta.

Esseissä historian tapahtumia ja olosuhteita kuvataan relationaalisten prosessien avulla, joissa luonnehditaan valtioita. Seuraavassa esimerkissä on relationaalisten prosessien alatyyppi, possessiivinen prosessi (Shore 1992: 249):

(20) Ensimmäisen maailmansodan jälkeen USA:lla oli kehittyneempää teknologiaa (ydinpommit) - -

Esimerkissä 20 LUONNEHDITTAVANA on USA ja LUONNEHTIJANA kehittyneempi teknologia (ydinpommit). Esimerkissä tuodaan jälleen esiin historian kontekstitietoa eli kuvaillaan kylmän sodan alkuun liittyvää historiallista tilannetta. Tähän viittaa prosessin olosuhteena oleva ajallinen määrittely ensimmäisen maailmansodan jälkeen ja se, että ydinpommeista ja valtioiden varustelutasosta ei puhuta oheisdokumenteissa.

Relationaaliset prosessit ovat aineistossani toiseksi yleisin prosessityyppi materiaalisten prosessien jälkeen. Kiinnostavaa on se, että relationaalisten prosessien avulla kuvataan selvästi eniten elottomia asioita eli käsitteitä ja nominaalistettua toimintaa sekä luonnehditaan valtioita. Tämä kertonee siitä, että kirjoittajat ovat jossain määrin sosiaalistuneet oppikirjoille, tieteelliselle kielelle ja eritteleville teksteille ominaiseen tapaan ilmaista asioiden välisiä suhteita ja kuvailla käsitteitä, mikä liittää esseevastauksen eritteleviin asiatekstilajeihin. Historian henkilöitä taas luonnehditaan relationaalisten prosessien avulla esseevastauksissa harvemmin. Valaisen seuraavien valtioita luonnehtivien relationaalisten prosessien avulla, mistä tässä voi olla kyse:

(21) Kuvan perusteella Yhdysvallat ja neuvostoliitto olivat siis molemmat syyllisiä sodan syttymiseen.

(22) Puheen mukaan Itä-Eurooppa on Neuvostoliiton etupiirissä, Venäjän vaikutuksen alaisina.

Esimerkki 21 havainnollistaa, kuinka esseevastauksissa yksi tapa esittää kannanottoja tehtävänannon kysymykseen on tehdä päätelmä kylmän sodan aloittajasta dokumentin perusteella (Paldanius 2017: 228). Useissa esseissä onkin prosesseja, joissa LUONNEHDitTAVANA ovat joko molemmat kylmän sodan osapuolet tai toinen niistä ja LUONNeHTIJANA syyllisyyteen tai aloittamiseen viittaava ilmaus kuten esimerkissä 21. Tämä selittää osaltaan sitä, miksi valtiot ovat henkilöitä useammin relationaalisten prosessien LUONNEHDitTAVANA, sillä vain harvoissa esseissä syylliseksi esitetään Stalin tai Churchill. Toinen syy valtioiden osuuteen relationaalisissa prosesseissa on se, että oheisdokumenteissa luonnehditaan valtioita ja kylmän sodan alun tilannetta. Tätä luonnehdintaa referoidaan esseissä, kuten esimerkissä 22, jossa johtoilmaus puheen mukaan ilmaisee Itä-Euroopan tilanteesta esitettävän kuvauksen olevan peräisin Churchillin puheesta. 
Paldanius Historiallisen toimijuuden rakentuminen lukiolaisten esseevastauksissa

\section{Toimijuuden vaihtelu historiallisen tiedon rakentumisessa}

Tässä artikkelissa olen tarkastellut historiallisen toimijuuden ja historiallisen tiedon rakentumista lukiolaisten kirjoittamissa dokumenttipohjaisissa esseissä, joiden aiheena on kylmän sodan aloittajan pohtiminen. Keskityin erityisesti esseisiin muodostuviin ideationaalisiin merkityksiin SF-teoreettisen prosessityyppianalyysin avulla. Analyysin tulkintakehykseen vaikuttivat esseiden tilannekontekstin muuttujat, kuten tehtävänanto, oheisdokumentit, opetus ja historian tiedonala. Tutkimuksen aineisto on melko pieni, 23 esseevastausta, minkä vuoksi havaintoni eivät ole yleistettävissä laajemmin. Toisaalta aineiston vahvuus on se, että se on yhden lukioryhmän ja saman opettajan opiskelijoilta eli esseevastausten tilannekontekstin muuttujat ovat samankaltaisia. Prosessityyppianalyysissa tekstit käydään läpi lausetasolla, joten menetelmä ei soveltuisikaan kovin laajan aineiston tarkasteluun. Tutkimukseni antaa siten yksityiskohtaisen kuvan yhdessä tekstitapahtumassa tuotetuista esseevastauksista ja kertoo, mitä niiden perusteella voidaan päätellä historian tekstitaidoista.

Tehtävänannon aihe, kylmä sota, käsittelee aseetonta poliittista konfliktia ja kietoutuu siihen, miten kylmän sodan osapuolet (yksittäiset johtajat, hallinto ja kansalaiset) suhtautuvat toisiinsa ja reagoivat toistensa toimiin. Aihe toistuu myös tehtävänantoon liittyvissä dokumenteissa, joissa kuvataan muun muassa valtioiden ja niiden päämiesten suhtautumista toisiinsa kylmän sodan alkuaikoina. Tehtävänannon aihe näkyy esseevastausten ideationaalisissa piirteissä siinä, että esseissä ei juuri puhuta konkreettisista tapahtumista. Sen sijaan esseissä esitetään dokumenteissa esiintyvien historiallisten henkilöiden sanomisia ja tuntemuksia, kuvataan kylmään sotaan osallistuneiden valtioiden reaktioita sekä kuvataan muutoksia valtioiden välisissä suhteissa ja historiallisissa olosuhteissa. Tämä näkyy myös siinä, miten prosessityypit jakautuvat koko aineistossa: Kaikkiaan siinä on 832 prosessia, joista suurin prosessityyppiryhmä ovat materiaaliset (297). Niistä kuitenkin vain vajaa neljännes (68) kuvastaa selvästi konkreettisempaa toimintaa (esim. tunkea, taistella) ja loput (229) ovat merkitykseltään abstraktimpia (esim. sallia, pakottaa, kieltää). Osa materiaalisista prosesseista taas kuvaa kausaalisuhteita (esim. johtaa, aiheuttaa). Relationaalisia prosesseja on toiseksi eniten (226) ja mentaalisia prosesseja sekä niiden alaryhmäksi luokiteltavia kommunikatiivisia prosesseja molempia 189, joten valtaosa esseiden prosesseista kuvaa jotain muuta kuin konkreettista materiaalista toimintaa.

Kylmän sodan historiallisista toimijoista kirjoitetaan esseissä vaihtelevilla tavoilla. Toimijana voi olla yksilöity henkilö, ihmiskollektiiviin viittaava valtio tai muu kylmän sodan osapuoli (esim. länsivallat), erittelemättömään ihmisryhmään viittaava passiivi tai jokin ei-inhimillinen abstrahoitu aiheuttaja. Osa tapahtumista esitetään myös ilman minkäänlaista aiheuttajaa tai toimijaa, jolloin historiatiedon esityksessä korostuvat asioiden väliset kausaaliset ja kronologiset suhteet inhimillisten toimijoiden intentioiden sijaan (ks. myös Väisänen 2005: 132).

Tehtävänannon vaatimus dokumenttien hyödyntämisestä näkyy suorimmin esseissä silloin, kun toimijoina ovat dokumenteissa mainitut henkilöt ja valtiot. Tarkastelemassani aineistossa henkilötoimijuus annetaan erityisesti Stalinille, kun taas länsivalloista puhutaan yleisemmin Yhdysvaltojen toimijuuden tai passiivin avulla. Tämä 
voi johtua Stalinin esiintymisestä oheisdokumenteissa, mutta ero on mahdollista tulkita myös niin, että Stalin edustaa puhtaammin itseään ja johtamaansa diktatuurista hallintoa, kun taas Yhdysvallat edustaa demokraattisemmin päätöksiä tekevää ihmisjoukkoa. Henkilötoimijuus voi olla oleellinen resurssi tehtävänannossa, johon liittyy henkilöitä käsitteleviä dokumentteja: perusteluissa tukeudutaan dokumenteissa esiintyvien ihmisten tunteista, sanomisista ja reaktioista tehtäviin tulkintoihin ja tehdään näin dokumentteihin perustuvaa päättelyketjua näkyväksi.

Koulukontekstissa tapahtumien erittely henkilötoimijuuden avulla voi siis olla aiheellista tämän tutkimuksen aineiston kaltaisten tehtävänantojen yhteydessä, joissa edellytetään historiallisten henkilöiden tuottamien pohjadokumenttien analysointia. Yksinomaan henkilökeskeisenä pysyttelevä selitystapa tosin saattaa jättää ulkopuolelle rakenteellisemman tason vaikutukset ja seuraukset, joihin nojaaminen taas on tyypillistä historioitsijoille (ks. Halldén 1998). Analyysini herättääkin kysymyksen, millaisia odotuksia esseevastauksia arvioivilla opettajilla on siitä, miten tehtävänantoon vastataan ja miten esimerkiksi dokumenttien erittely kielellisesti ilmaistaan. Samalla herää myös kysymys, tuodaanko nämä odotukset opiskelijoille näkyväksi. Äidinkielen ja kirjallisuuden oppiaineessa aineistoja tulkitsevissa tehtävissä odotetaan päätelmien perustelemista tiukasti aineistona olevan tekstin perusteella (ks. Leino 2006; Valtonen 2011; Äidinkielen kokeen määräykset 2017). Historiassa kuitenkin odotetaan myös kontekstitiedon esittämistä (esim. Rantala \& Veijola 2016) ja laajempien historiallisten yhteyksien selittämistä (esim. Coffin 2006: 6; Rantala \& Ahonen 2015).

Halldén (1998) kutsuu historian selittämistä historiallisesti merkittävien henkilöiden välityksellä historiatiedon personoinniksi. Tarkastelemissani esseevastauksissa myös valtiot ovat toimijoina tunteita ilmaisevissa prosesseissa. Tällaisen historian selittämisen voi ymmärtää niin, että valtioiden katsotaan edustavan kansalaisista muodostuvaa ihmiskollektiivia tai valtion päättäjiä, jolloin valtiot voivat olla toimijoina yksittäisen ihmisen ominaisuuksiin viittaavissa fyysisissä ja psyykkisissä toiminnoissa. Historiatiedolle onkin tyypillistä se, että poliittisia ja sosiaalisia rakenteita ilmaistaan mentaalisten toimintojen avulla eli valtioita personoidaan (Halldén 1998: 133). Esseevastauksissa valtioiden reaktioista puhuminen heijastelee siis historian diskurssiin sosiaalistumista. Samanlainen puhetapa on tyypillistä myös politiikkaa käsitteleville pääkirjoitusteksteille (Heikkinen 1999: 146).

Historiallinen toimija tai kokija on eksplikoitu prosesseissa, joissa on henkilö- ja valtiotoimijoita. Esseissä kuvataan historiallisia olosuhteita, muutoksia olosuhteissa sekä syy-seuraussuhteita tapahtumien välillä myös niin, että toimijoiden sijaan korostuvat asioiden väliset suhteet. Erityisesti tällaisessa muutoksen kuvailussa hyödynnetään kieliopillista metaforaa, jonka avulla voidaan korostaa historian tekstitaidoille oleellisia syy-seuraussuhteita. Suhteita esitetään erilaisten kausaalisuutta ilmentävillä verbeillä, joiden välillä on eroja kausaalisuhteen ehdottomuuden ja selvärajaisuuden suhteen. Tapahtumien välisiä suhteita sekä historiallisia olosuhteita kuvataan myös relationaalisten prosessien avulla.

Muutosta ja suhteita kuvaavien prosessien hyödyntäminen on tyypillistä abstraktille ja erittelevälle kielelle (Halliday \& Martin 1993; Karvonen 1995: 167), mikä yhdistää esseevastauksia niiden tilannekontekstiin kuuluviin muihin diskursseihin, kuten oppikirja- 
tekstiin ja myös akateemiseen kirjoittamisen tapaan. Tutkimuksien mukaan historian syy-seuraussuhteiden esittämisessä kieliopillinen metafora ja nominaalimuodot ovat erityisen tärkeä kielellinen resurssi (Coffin 1997: 217; Schleppegrell \& de Oliveira 2006). Kieliopillinen metafora mahdollistaa dokumenttien erittelyn yhteydessä asiasisällön tiivistämisen, syy-seuraussuhteiden korostamisen sekä muutoksen ja jatkuvuuden ilmaisemisen, jotka kaikki ovat historian tekstitaitojen kannalta tärkeitä piirteitä.

Muutosta ja suhteita kuvaavissa prosesseissa puhutaan myös historian käsitteistä ja historian tapahtumista, jotka eivät ilmene oheisdokumenteista. Niiden voidaan siis katsoa esittävän opiskelijalla olevaa historian kontekstitietoa, joka liittyy käsiteltävään aiheeseen. Historian käsitteitä selitettäessä ei välttämättä mainita tapahtuman aiheuttajaa myöskään siksi, että kuvauksen kohteena olevat asiat eivät välttämättä ole olleet jonkin tahon päämäärä, vaan kyseessä voi olla jälkikäteen historian tiedonalalla annetut nimitykset tapahtumille (vrt. Walsh 1974). Tiedon rakentumisen kannalta tapahtumien aiheuttajien eksplikoiminen saattaisi siis yksinkertaistaa tapahtumia ja jopa vääristää tietoa (ks. Halldén 1998).

Tarkastelemani esseevastaukset ovat aineistopohjaisia ja pohtivia lukiolaisten esseitä, joissa pyritään vastaamaan koetilanteessa annettuun tehtävänantoon lukion asettamien tavoitteiden mukaisesti; kylmästä sodasta voitaisiin toisenlaisten tavoitteiden ja toisenlaisen kieliyhteisön vaikutuksesta kirjoittaa lukemattomilla muunlaisilla tavoilla. Kuten analyysini osoitti, esseevastauksiin on suodattunut niiden alaan (field, Halliday 1973) kuuluvien muuttujien, kuten tehtävänannon, oheisdokumenttien, kouluopetuksen tavoitteiden ja historian tiedonalan piirteitä. Kun tiedonalakohtaiset tekstitaidot ja siten historiallisten tiedonmuodostustapojen opettaminen korostuvat opetussuunnitelmissa, olisi tärkeää tehdä näkyväksi se, mitä opiskelijoilta oikeastaan odotetaan erilaisten tehtävänantojen kohdalla silloin, kun tehtävä edellyttää dokumenttien tulkitsemista historiallisen tiedon muodostamisessa.

Historian tiedonalakohtainen diskurssi ja esseevastauksen vaatimat tekstitaidot vaikuttaisivat fokusoituvan toisin kuin esimerkiksi äidinkielen ja kirjallisuuden oppiaineessa. Historian oppiaineessa vaaditaan esimerkiksi historian kontekstitiedon esittämistä, mutta toisaalta sisältötietoa ja sen ilmaisemisen tapoja ei voi erottaa toisistaan, sillä esimerkiksi tarkastelemani toimijuuden ilmaisemisen tavat vaikuttavat siihen, millaisena historiallinen tieto representoituu. Analyysi tukee ajatusta siitä, että historiatieto ei rakennu esseevastauksiin tyhjiössä: esseevastausten tuottaminen on osa niihin liittyvää sosiaalista tilannetta, eikä kirjoittamistakaan siten voida pitää ainoastaan yleisesti sovellettavissa olevana taitona. Tekstitaitojen tiedonalakohtaisuudesta tiedostuminen voisi siis mahdollistaa aidosti sen pohtimisen, mitä monilukutaito ja tekstitaidot lukiossa eri oppiaineissa tarkoittavat.

Toimijuuden tarkastelun yhteydessä tein huomioita esseissä esitettävistä syy-seuraussuhteista ja tapahtumien ajallisista ulottuvuuksista lausetasolla. Jatkotutkimuksissa esseen kokonaisuuden tarkastelu mahdollistaisi myös sen analysoimisen, miten esseissä argumentoidaan erilaisia kantoja kylmän sodan aloittajan suhteen ja millaisia syyseuraussuhteita tapahtumien välille rakennetaan koko tekstin tasolla. Jatkotutkimuksissa olisi kiinnostava tarkastella myös historiatiedon tulkinnallisuuden piirteitä siitä näkökulmasta, miten kirjoittaja itse esittää suhtautuvansa esseissä tekemiinsä tulkintoihin: 
miten varmana tieto esitetään, miten kirjoittaja osoittaa tietonsa lähteet ja millaisia keinoja hänellä on epävarmuuden ja tulkintojen moninaisuuden esittämiseen. Näihin piirteisiin pääsisi käsiksi tarkastelemalla erilaisia suhtautumisen ilmauksia sekä erityisesti relationaalisissa prosesseissa esitettäviä arviointeja tapahtumien merkityksellisyydestä.

\section{Lähteet}

Berg, MaArit 2011: Referointi, erittelymuotti ja tekstitaidon koe. - Virittäjä 115 s. 317-348.

Coffin, Caroline 1997: Constructing and giving value to the past. An investigation into secondary school history. - Frances Christie \& James Martin (toim.), Genre and institutions. Social processes in the workplace and schools s. 197-229. London: Continuum.

2006: Historical discourse. The language of time, cause and evaluation. London: Continuum.

Fang, Zhinui - CoAtoam, Suzanne 2013: Disciplinary literacy and what you want to know about it. - Journal of adolescent \& adult literacy 56 s. 627-632. https://doi. org/10.1002/jaal.190.

Greene, StuART 1994: The problems of learning to think like a historian. Writing history in the culture of the classroom. - Educational psychologist 29 (2) s. 89-96. https://doi. org/10.1207/s15326985ep2902_4.

Halldén, Ola 1998: Personalization in historical description and explanations. - Learning and instruction 8 (2) s. 131-139. https://doi.org/10.1016/s0959-4752(97)0oo12-1.

Halliday, M. A. K. 1973: Explorations in the functions of language. London: Arnold.

- 1978: Language as social semiotic. The social interpretation of language and meaning. London: Arnold.

2014 [1985]: An introduction to functional grammar. Uudistettu yhdessä M. I. M. Matthiessenin kanssa. London: Arnold.

Halliday, M. A. K. - Martin, J. R. 1993: Writing science. Literacy and discursive power. Pittsburg: University of Pittsburg Press.

Halliday, M. A. K. - Matthiessen, Christian 1999: Construing experience through meaning. A language based approach to cognition. London: Continuum.

Harmanen, Minna 2016: Monilukutaito laajentaa opetuksen tekstitietoisuutta. Kielitietoinen käänne opetussuunnitelman perusteissa. - Kaisa Leino \& Outi Kallionpää (toim.), Monilukutaitoa digiaikaan. Lukemisen ja kirjoittamisen uudet haasteet ja mahdollisuudet. Äidinkielen opettajain liiton vuosikirja 2016 s. 10-22.

HEIKKINEN, VESA 1999: Ideologinen merkitys kriittisen tekstintutkimuksen teoriassa ja käytännössä. Helsinki: Suomalaisen Kirjallisuuden Seura.

Historian kokeen hyvän vastauksen piirteet 2015. Historian koe 14.9.2015. Ylioppilastutkintolautakunta. https://www.ylioppilastutkinto.fi/images/sivuston_tiedostot/Hyv_vast_piirt/ FI_2015_S/2015_S_HI.pdf (14.11.2017).

HylAnd, Ken 1990: A genre description of an argumentative essay. - RELC Journal 21 (1) s. 66-78. https://doi.org/10.1177/003368829002100105.

ISK = Hakulinen, Auli - Vilkuna, Maria - Korhonen, Rittta - Koivisto, Vesa - Heinonen, Tarja Riıtta - Alho, Irja 2004: Iso suomen kielioppi. Helsinki: Suomalaisen Kirjallisuuden Seura.

Juvonen, Riıt ta 2011: Toisesta äänestä omaan ääneen. Uskoa-, ajatella-, luulla- ja sanoarakenteet ylioppilasaineissa. - Anneli Kauppinen, Hanna Lehti-Eklund, Henna MakkonenCraig \& Riitta Juvonen (toim.), Lukiolaisten äidinkieli. Suomen- ja ruotsinkielisten lukioiden 
opiskelijoiden tekstimaisemat ja kirjoitustaitojen arviointi s. 231-262. Helsinki: Suomalaisen Kirjallisuuden Seura.

— 2014: Kirjoitelma ja tekijän ääni. Kehystämisen yhdyslauseet suomenkielisen ylioppilasaineen dialogisuuden hallinnassa. Helsingin yliopisto.

Karvonen, Pirjo 1991: Kieliopillinen metafora ja sen vaikutukset tekstissä. - Tapani Lehtinen \& Susanna Shore (toim.), Kieli, valta ja eriarvoisuus. Esitelmiä 18. kielitieteen päiviltä s.149-165. Helsingin yliopiston suomen kielen laitos.

— 1995: Oppikirjateksti toimintana. Helsinki: Suomalaisen Kirjallisuuden Seura.

Lampinen, ArJA 2005: Essee. Kirjoittajan ABC-kortti. http://webcgi.oulu.fi/oykk/abc/tekstinhuolto/tekstilajeja/essee/ (1.6.2017).

Leinhardt, Gaea - Young, Kathleen 1998: Writing from primary documents. - Written communication 15 (1) s. 25. https://doi.org/10.1177/0741088398015001002.

Leino, Pentti 2006: Äidinkielen koe ja tekstitaidot. - Virittäjä 110 s. 590-598.

LOPS 2015 = Lukion opetussuunnitelman perusteet 2015. Opetushallitus. http://www.oph.fi/ download/172124_lukion_opetussuunnitelman_perusteet_2015.pdf (17.11.2017).

LuUkKa, Minna-Riıt ta 2002: M. A. K. Halliday ja systeemis-funktionaalinen kielitiede. - Hannele Dufva \& Mika Lähteenmäki (toim.), Kielentutkimuksen klassikoita s. 89-124. Jyväskylän yliopisto: Soveltavan kielentutkimuksen keskus.

_ 2009: Tekstitaidot. Teksteistä käytänteisiin. - Minna Harmanen \& Tuija Takala (toim.), Tekstien pyörityksessä. Tekstitaitoja alakoulusta yliopistoon s. 13-25. Äidinkielen opettajain liiton vuosikirja 2009.

- 2013: Opetussuunnitelmat uudistuvat. Tekstien lukijasta ja kirjoittajasta monilukutaituriksi. - Kieli, koulutus ja yhteiskunta 4 (5). http://www.kieliverkosto.fi/article/opetussuunnitelmat-uudistuvat-tekstien-lukijasta-ja-kirjoittajasta-monilukutaituriksi/.

LÖFSTRÖM, JAN - HAKKARI, JOHANNA 2003: Kohti antropologista historiandidaktiikkaa. - Historiallinen Aikakauskirja 2/2003 s. 318-326.

Makkonen-Craig, Henna 2008: Neljä näkökulmaa erääseen tekstilajiin. Äidinkielen ylioppilaskokeen tehtävänannot 2003-2006. - Virittäjä 112 s. 207-234.

— 2010: Ylioppilasaine ja päättökokeen tavoitediskurssi. Genre ja varjogenre. - Hanna Lappalainen, Marja-Leena Sorjonen \& Maria Vilkuna (toim.), Kielellä on merkitystä. Näkökulmia kielipolitiikkaan s. 206-252. Helsinki: Suomalaisen Kirjallisuuden Seura.

Martin, J. R. 2002: Writing history. Construing time and value in discourses of the past. - Mary Schleppegrell \& Cecilia Colombi (toim.), Developing advanced literacy in first and second languages. Meaning with power s. 87-118. Mahwah: Erlbaum. https://doi. org/10.4324/9781410612298.

Moje, Elizabeth - Stockdill, Darin - Kim, Katherine - Kim, Hyun-ju 2011: The role of text in disciplinary learning. - Michael Kamil, David Pearson, Elizabeth Moje \& Peter Afflerbach (toim.), Handbook of reading research vol. IV s. 453-486. New York: Routledge. https://doi.org/10.4324/9780203840412.ch20.

Mäntynen, Anne 2006: Näkökulmia tekstin ja tekstilajin rakenteeseen. - Anne Mäntynen, Susanna Shore \& Anna Solin (toim.), Genre - tekstilaji s. 42-71. Helsinki: Suomalaisen Kirjallisuuden Seura.

Oliveira, Luciana DE 2011: Knowing and writing school history. The language of students' expository writing and teachers' expectations. Purdue University: Information Age.

Pajunen, Anneli 2001: Argumenttirakenne. Asiantilojen luokitus ja verbien käyttäytyminen suomen kielessä. Helsinki: Suomalaisen Kirjallisuuden Seura.

PALdAniUs, Hilkka 2017: Historian esseevastauksen funktionaalinen rakenne. - Sirkku Lato- 
maa, Emilia Luukka \& Niina Lilja (toim.), Kielitietoisuus eriarvoistuvassa yhteiskunnassa. AFinLAn vuosikirja 2017 s. 219-238. Suomen soveltavan kielitieteen yhdistys AFinLA. https://journal.fi/afinlavk/article/view/60725.

Pietikäinen, SARi - Mäntynen, Anne 2009: Kurssi kohti diskurssia. Tampere: Vastapaino.

RAnTAla, JUKKA 2012: How Finnish adolescents understand history. Disciplinary thinking in history and its assessment among 16-year-old Finns. - Education Sciences 2 s. 193-207. https://doi.org/10.3390/educsci2040193.

Rantala, Jukka - Ahonen, Sirkka 2015: Ajan merkit. Historian käyttö ja opetus. Helsinki: Gaudeamus.

Rantala, Jukka - Veijola, Anna 2016: Historiallisen tiedonmuodostuksen periaatteet hukassa. Tapaustutkimus nuorten historian tekstitaidoista. - Historiallinen Aikakauskirja 3/2017 s. 267-277.

SChleppegrell, MARY 2001: Linguistic features of the language of schooling. - Linguistics and education 2 s. 431-445. https://doi.org/10.1016/so898-5898(o1)ooo73-0.

2004: The language of schooling. A functional linguistic perspective. New York: Routledge.

Schleppegrell, Mary - Oliveira, Luciana De 2006: An integrated language and content approach for history teachers. - Journal of English for Academic Purposes 5 s. 254-268.

Seixas, Peter - Morton, Tom 2013: The big six. Historical thinking concepts. Toronto: Nelson Education.

SHORE, Susanna 1992: Aspects of a systemic-functional grammar of Finnish. Sydney: Macquarie University.

_ 2012a: Kieli, kielenkäyttö ja kielenkäytön lajit systeemis-funktionaalisessa teoriassa. - Vesa Heikkinen, Eero Voutilainen, Petri Lauerma, Ulla Tiililä \& Mikko Lounela (toim.), Genreanalyysi. Tekstilajitutkimuksen käsikirja s. 131-157. Helsinki: Gaudeamus.

2012b: Systeemis-funktionaalinen teoria tekstien tutkimisessa. - Vesa Heikkinen, Eero Voutilainen, Petri Lauerma, Ulla Tiililä \& Mikko Lounela (toim.), Genre-analyysi. Tekstilajitutkimuksen käsikirja s. 158-185. Helsinki: Gaudeamus.

Thibault, Paul 1987: An interview with Michael Halliday. - Terry Threadgold, Ross Steele \& M. A. K. Halliday (toim.), Language topics. Essays in honor of Michael Halliday s. 601-627. Amsterdam: John Benjamins. https://doi.org/10.1075/z.lt1.81thi.

Valtonen, PäIVI 2011: Äidinkielen tekstitaidon ylioppilaskokeen tuottamistehtävien haasteita ja mahdollisuuksia. - Virittäjä 115 s. 350-362.

2012: Abiturientti uutistoimittajana. Tekstilajin taju ja uutisen tuottaminen äidinkielen tekstitaidon kokeessa. Turun yliopisto.

Veijola, Anna 2016: Historiatietoisuus, historiallinen ajattelu ja historian tekstitaidot. Uuden opetussuunnitelman moninaiset lähtökohdat. - Kasvatus ja aika 10 (2) s. 6-18.

Veijola, Anna - Mikkonen, Simo 2016: Historical literacy and contradictory evidence in Finnish high school setting. The Bronzen Soldier of Tallinn. - Historical Encounters 3 (1) S. 1-16.

VÄISÄNEN, JA AKKO 2005: Murros oppikirjojen teksteissä vai niiden taustalla? 1960- ja 199o-luvun historian oppikirjat kriittisen diskurssianalyysin silmin. Joensuun yliopisto.

Walsh, Henry William 1974: Colligatory concepts in history. - Patrick Gardiner (toim.), The philosophy of history s. 127-144. Kuudes painos. Oxford: Oxford University Press.

Äidinkielen kokeen määräykset 2017. Ylioppilastutkintolautakunta. https://www.ylioppilastutkinto.fi/images/sivuston_tiedostot/Ohjeet/Koekohtaiset/fi_maaraykset_aidinkieli.pdf (14.11.2017). 


\section{Verkkoliite}

Ks. artikkelin verkkoversio osoitteessa https://journal.fi/virittaja.

\section{The construction of historical agency in students' essays}

The article examines the representation of historical agency as part of constructing knowledge in document-based essays written by upper secondary school students. The data studied consists of 23 history essays, in which the students were asked to discuss what instigated the Cold War. The article is based on a sociocultural view of literacies and on the concept of disciplinary literacies, and the linguistic features of the essays are therefore linked to the knowledge construction features of the discipline of history.

The theoretical and methodological framework of the article is based on the systemic-functional language theory. Historical agency is approached through a process type analysis within the transitivity system of the theory, focusing on who or what is represented as an agent behind the processes, and the ways in which historical events are represented as actions. According to the analysis, historical agency alternates between identified people and human collectives. Abstract agents and relational processes can also place human agency into the background.

The essays reflect the texts and discourses within their context of situation. In constructing agency, some general features of analytical language are used. The alternation of agency between human beings, human collectives, and abstract agents also intertwines with the genre and the assignment of a school essay. Furthermore, it is linked to the important features of knowledge construction in the discipline of history, such as cause and correlation and the interpretative nature of knowledge. 


\section{Historiallisen toimijuuden rakentuminen lukiolaisten esseevastauksissa}

Artikkelissa tarkastellaan historiallisen toimijuuden representoitumista osana tiedon rakentumista lukiolaisten kirjoittamissa dokumenttipohjaisissa esseissä. Tutkimuksen aineistona on 23 historian esseetä, joiden tehtävänantona on pohtia kylmän sodan aloittajaa annetun oheisaineiston valossa. Artikkelissa tekstitaitoja lähestytään sosiokulttuurisesti rakentuvina ja tiedonalakohtaisina taitoina. Esseiden kielen piirteiden tarkastelu sidotaan siis historian tiedonalan tiedonmuodostukseen sekä koulukontekstiin liittyviin piirteisiin.

Artikkelin teoreettinen ja metodologinen viitekehys pohjautuu systeemisfunktionaaliseen kieliteoriaan. Historiallista toimijuutta lähestytään transitiivisuussysteemin sisällä tehtävän prosessityyppianalyysin avulla eli tarkastellaan, kuka tai mikä esseissä esitetään tapahtumia aikaansaavaksi tahoksi ja millaisena toimintana tapahtumat näyttäytyvät. Analyysin perusteella historiallinen toimijuus vuorottelee esseissä yksilöityjen henkilöiden ja ihmisjoukkoon viittaavien sanojen, kuten valtioiden, välillä. Inhimillinen toimijuus voidaan myös viedä taka-alalle abstraktien toimijoiden ja suhteita kuvaavien prosessien avulla.

Tutkimuksen perusteella esseevastaukset heijastelevat niiden tilannekontekstiin kuuluvia tekstejä ja diskursseja: Toimijuuden rakentamisessa hyödynnetään yleisiä analyyttisen kielen piirteitä. Toimijuuden tasojen vaihtelut henkilöiden, ihmisjoukkojen ja abstraktien toimijoiden välillä kietoutuvat myös esseen tekstilajiin ja tehtävänannon esseille asettamaan kehykseen sekä historian tiedonalan tiedonrakennustapoihin, kuten tulkinnallisuuteen ja syy-seuraussuhteiden esittämiseen.

Kirjoittajan yhteystiedot (address):

etunimi.sukunimi@jyu.fi

Kirjoittaja on väitöskirjatutkija Jyväskylän yliopistossa. 